\title{
Effects of mRNA Untranslated Regions on Translational Efficiency of NMDA Receptor Subunits
}

\author{
Antonius M.J. VanDongen Hendrika M.A. VanDongen \\ Department of Pharmacology and Cancer Biology, Duke University Medical Center, Durham, N.C., USA
}

\author{
Key Words \\ Protein synthesis - mRNA - Ribosome $\cdot 5^{\prime}$-UTR $\cdot 3^{\prime}$-UTR . \\ mRNA trafficking $\cdot$ mRNA stability
}

\begin{abstract}
Because NMDA receptors play critical roles in both neuronal survival and plasticity, their expression levels need to be carefully controlled. The number of functional NMDA receptors is temporally and spatially regulated at a hierarchy of levels, from gene transcription to protein trafficking. In this review we will focus on mechanisms for controlling functional expression of NMDA receptors that involve altering the efficacy of mRNA translation. One advantage of this level of control is that new receptors can be generated both rapidly and locally in response to appropriate synaptic activity patterns.
\end{abstract}

Copyright @ 2004 S. Karger AG, Basel

\section{Introduction}

NMDA receptors are a subclass of ionotropic glutamate receptors [1], pharmacologically characterized by their selective agonist N-methyl- $D$-aspartate. They have many unusual properties that set them apart from nonNMDA glutamate receptors and other ligand-gated ion channels. NMDA receptors display a pronounced voltage dependence [2, 3], a high calcium permeability [4], and a requirement for two co-agonists: glutamate and glycine. They are modulated by many physiological factors, including $\mathrm{pH}$ [5], redox status [6], S-nitrosylation [7], soft metal divalent cations $\left(\mathrm{Zn}^{2+}, \mathrm{Cd}^{2+}\right)$ [8], heavy metals $\left(\mathrm{Pb}^{2+}\right)$ [9] and polyamines [10,11]. NMDA receptors play critical roles in both the development of the central nervous system $[12,13]$ and the maintenance of plasticity in the adult brain $[14,15]$. Whereas NMDA receptor activity is required for neuronal survival [16], overstimulation of the receptor by excessive glutamate release following ischemic episodes or other brain insults results in neurodegeneration $[17,18]$. Insufficient stimulation is equally deleterious, since NMDA receptor hypofunction can cause several neuronal pathologies, including cognition and memory deficits [19,20]. Abnormal low expression of NMDA receptors has been proposed to underlie schizophrenia [21, 22]. From the above, it seems paramount that neurons carefully control the level of functional NMDA receptors. This goal can be achieved by a number of widely different molecular and cellular mechanisms.

Regulation of gene transcription is often considered to be the 'classic' mechanism by which protein levels can be altered. Transcriptional control of glutamate receptors is discussed in Dingledine et al. [1]. There are five mammalian genes encoding NMDA receptor subunits: NR1 and NR2A-D. Two additional genes $(\mathrm{NR} 3 \mathrm{~A}+\mathrm{B})$ that formally belong to this family due to their sequence homology form

\begin{tabular}{ll}
\hline KARGER & ( 2004 S. Karger AG, Basel \\
1424-862X/04/0134-0194\$21.00/0 \\
$\begin{array}{l}\text { Fax +41613061234 } \\
\begin{array}{l}\text { E-Mail karger@karger.ch } \\
\text { www.karger.com }\end{array}\end{array}$ & $\begin{array}{l}\text { Accessible online at: } \\
\text { www.karger.com/ng }\end{array}$
\end{tabular}

Antonius M.J. VanDongen
Department of Pharmacology and Cancer Biology
Duke University Medical Center
PO Box 3813, Durham, NC 27710 (USA)
Tel. +1919681 4862, Fax +1919684 8922, E-Mail vando005@mc.duke.edu 
functional glycine receptors [23] and are therefore outside the scope of this review. Functional NMDA receptors are heteromeric assemblies of four subunits arranged around a central aqueous pore. The NR1 subunit is obligatory, while incorporation of specific NR2 subunits endows NMDA receptors with unique properties [24, 25]. Promoter regions have been characterized for NR1 and NR2A-C [26-31], while regulation by transcription factors and hormones has been documented [32-40]. The product of the gene transcription process is a non-functional, pre-mRNA molecule, which is processed in the nucleus to a mature mRNA, after which it is exported to the cytoplasm where it can be translated into the protein it encodes. An assumption often made (in gene transcription studies and elsewhere) is that all mRNAs are efficiently and uniformly translated, such that cellular mRNA levels reliably predict protein levels. Consequently, transcription efficiency would then be the main determinant of protein expression levels. However, as discussed below, this relatively simple scenario does not hold up in general. Discrepancies between protein and mRNA levels are numerous, and have also been documented for NMDA receptor subunits [41-43].

Functional NMDA receptors are localized to excitatory synapses in the soma and dendrites of neurons, where they are part of a large, multi-protein signaling complex [44], consisting of receptors and channels, scaffolding and adaptor proteins, cytoskeletal elements, kinases, phosphatases and cell adhesion molecules [45]. Calcium influx through NMDA receptors residing in this complex directly affects the function of calcium-sensitive components of this macromolecular machine, resulting in a highly localized signaling cascade, and a prolonged alteration of synaptic strength. A distinct pool of functional NMDA receptors is found at extra-synaptic locations, which couples to a unique signaling cascade [46]. NMDA receptors can be rapidly exchanged between these two functionally distinct pools. Receptors are also subject to cycling between a physiologically inactive intracellular pool and the plasma membrane [47-50]. Trafficking of NMDA receptors is regulated by various signaling pathways [51-53] and appears to become more prominent late in development [54].

The remainder of this review will focus on translational control mechanisms for regulating NMDA receptor expression. Translation of mRNA represents a critical step in protein expression, hierarchically localized to a level that is intermediate between gene transcription and protein trafficking. Transcription is rendered ineffective if the produced mRNAs are translationally blocked, while protein trafficking relies of constant protein production to make up for degradation losses. Translation regulation therefore has the potential to be a major determinant of NMDA receptor expression levels. In the following sections, the multitude of steps involved in mRNA processing, trafficking and translation are discussed. Of particular interest are the untranslated regions (UTRs) found in mature mRNAs, because of their critical role in determining translation efficacy. Where possible, data available for NMDA receptors will be discussed.

\section{Processing of Pre-mRNA}

Mammalian gene transcription results in the generation of an mRNA precursor, which is usually nonfunctional and retained in the nucleus. It consists of series of coding exons, interspersed by noncoding introns. A brief description will be given of the steps involved in the nuclear processing of a pre-mRNA molecule, which culminate in the appearance of a (potentially) translatable, mature mRNA in the cytoplasm (fig. 1). The figure may incorrectly suggest that this is a linear process in which each step needs to finish before the next one can ensue. In fact, the pre-mRNA modifications shown are co-transcriptional, taking place during mRNA synthesis. RNA polymerase II, the enzyme that synthesizes the premRNA, directs the organization of the processing complexes [55-57].

\section{Association with Processing Factors}

An early event in the processing of the naïve premRNA is the association with various proteins and small nuclear RNAs (snRNAs) [58], responsible for mRNA processing [59-61]. The molecular make-up of the premRNA/snRNA/protein complex changes during processing. Fully processed, mature mRNAs may be exported from the nucleus in a complex with heterogeneous nuclear ribonucleoproteins (hnRNPs) as hnRNP particles, the composition of which affects their stability and translation.

\section{Capping}

The 5'-end of the pre-mRNA is covalently modified ('capped') by addition of a 7-methylguanosine group. This 5 '-cap structure has many roles: it protects the mRNA from degradation, controls splicing of the fist exon, facilitates nuclear export, and enables assembly of the translation initiation complex [62-66]. 


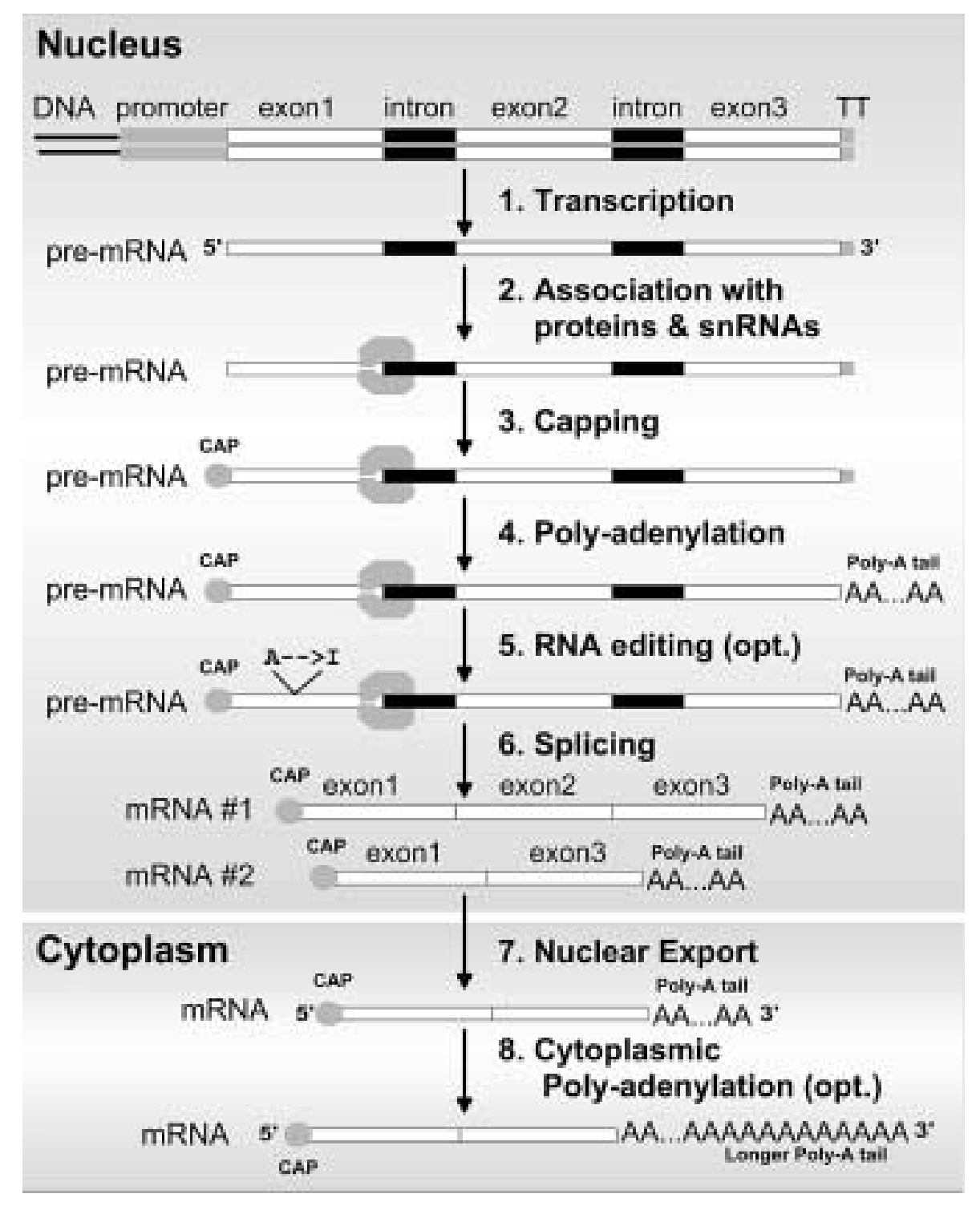

Fig. 1. Diagram of pre-mRNA processing Details are described in the text.

Polyadenylation

The 3'-end of the mRNA is also modified, by cleavage downstream of the transcription termination signal [67] and subsequent addition of a string of adenosine nucleotides [68]. The poly-A tail that results is important for both mRNA stability and translation efficacy, with its length being a critical determinant of both.

\section{RNA Editing}

A small subset of mammalian mRNAs is subjected to an 'editing' process, in which specific nucleotides are substituted. Adenosines and cytidines can be converted to inosines and uridines, respectively, by RNA-specific deaminases. Depending on whether the editing occurs in the coding region, UTRs or introns, these base substitutions may affect protein function, splicing, mRNA stability or translation efficacy [69-73]. Interestingly, RNA editing appears to be most prominent in the nervous system [72]. Several members of the ionotropic glutamate family have been shown to undergo A-to-I RNA editing, which greatly affects their calcium permeability [74]. The physiological importance of this process is underscored by the fact that recombinant mice unable to edit the GluR2 AMPA receptor mRNA develop early-onset epilepsy [75]. Recent identification of novel targets for RNA editing has suggested that untranslated regions may be more elabo- 


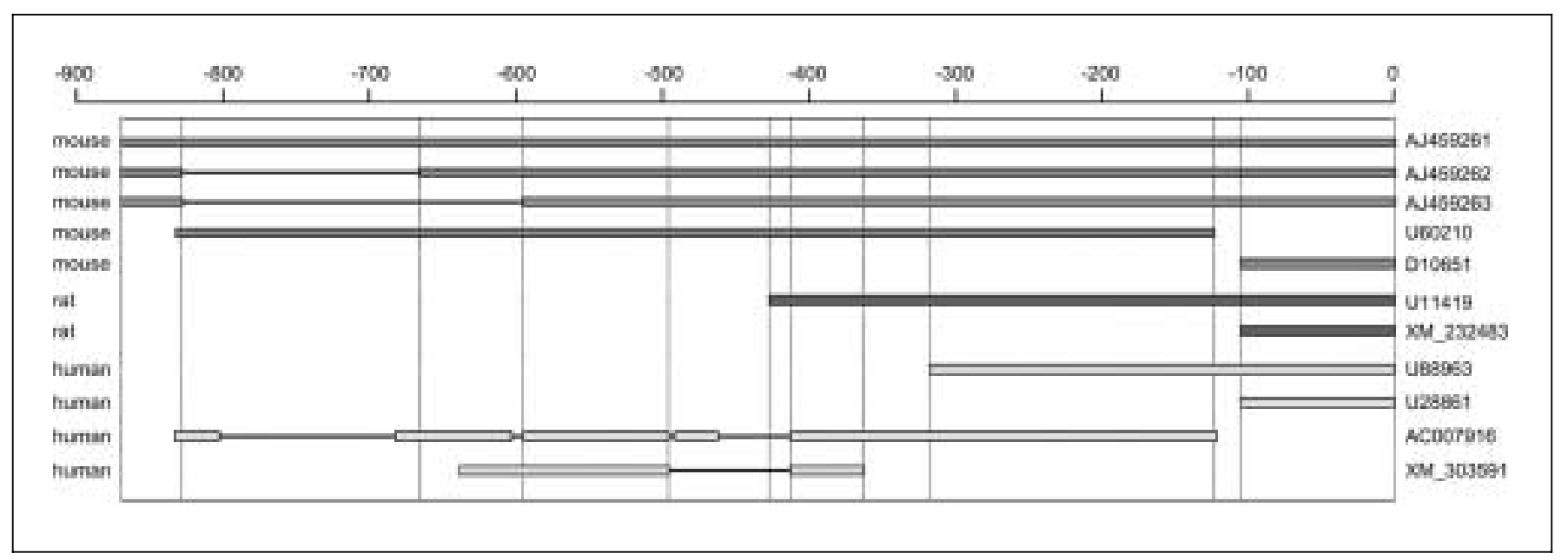

Fig. 2. Alternative splicing and conservation in the NR2B $5^{\prime}$-UTR. Homologous regions between human, mouse and rat NR2B 5'-UTR sequences were found by a nonredundant Blast search, using the top sequence as template. Homologous regions are indicated by solid colored boxes. Genbank accession numbers are provided for each sequence on the right.

rately edited than coding regions [73], although the functional importance of this still needs to be evaluated.

\section{Splicing}

Before the mRNA leaves the nucleus, the non-coding intronic regions of the pre-mRNA need to be removed by a process termed splicing. This task is accomplished by a large protein-RNA complex termed the spliceosome [76]. Not all exons present in the pre-mRNA are necessarily included in the final mRNA: by selectively including only a subset of the exons, alternative splicing can give rise to several mRNA species from the same pre-mRNA [7779]. Alternative splicing is widespread in humans, affecting $40-60 \%$ of all genes, thereby substantially expanding the functional complexity of the genome [80]. Again, this mechanism for generating additional protein diversity seems to be particularly promiscuous in the nervous system [81]. Eight isoforms are produced for the NMDA receptor NR1 subunit by alternative splicing, with two alternatives for one N-terminal and two $\mathrm{C}$-terminal cassettes, which affect proton sensitivity and subcellular distribution [82, 83]. The non-NMDA glutamate receptors are also subject to functionally important alternative splicing [1]. Several NMDA receptor subunits display alternative splicing in the untranslated regions of their mRNAs, suggesting a possible role in translational control. Figure 2 illustrates this for the $5^{\prime}$-UTR of the NR2B mRNA.

Roles of NMDA Receptor UTRs

\section{Nuclear Export}

Only mature mRNAs that are capped, polyadenylated, possible edited and spliced, are able to leave the nucleus through a highly regulated export process [84]. Specific nuclear export factors responsible for this quality control mediate the transport of mRNAs from the co-transcriptional processing sites to the nucleopore complex [85-88]. RNA binding proteins are being characterized that can organize subsets of related mRNAs into functional units which leave the nucleus together $[84,85]$.

\section{Cytoplasmic Polyadenylation}

Processing of mRNAs does not necessarily end upon exit of the nucleus. First described for maternal mRNA in oocytes, poly-A tails of cytoplasmic mRNAs can be lengthened by polyadenylation, thereby increasing their stability and translatability [89]. In neurons, this mechanism of cytoplasmic polyadenylation has been described to underlie the NMDA receptor activity-dependent increase in translatability of the mRNA for alpha-CaMKII $[90,91]$.

\section{mRNA Domain Structure}

Cytoplasmic mRNAs have a domain structure that is illustrated in figure 3. A central coding region is flanked on either side by UTRs, which play unique roles in regulating protein synthesis. The coding region is character- 
Fig. 3. Domain structure of mature mRNAs. Details are provided in the text.

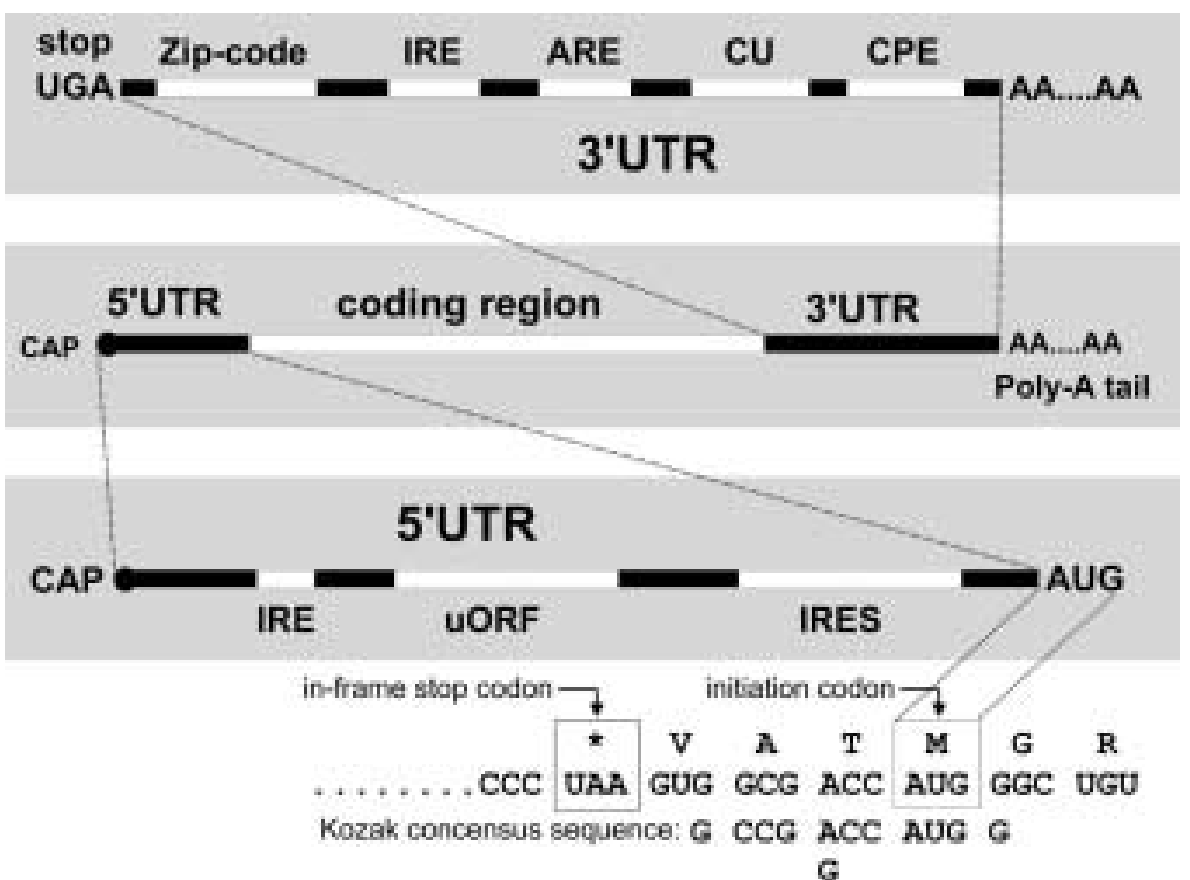

$\mathrm{G}$ ized by a long open reading frame (ORF), a sequence of codons starting with the initiation codon (AUG) encoding a methionine, and ending with one of three stop codons (UAG, UAA or UGA). During protein synthesis, the coding region is used as a template by the ribosomes.

Ribosomes mediate peptide chain elongation: they recruit matching tRNAs to appropriate codons in the coding region by base-pairing, adding amino acids to the nascent protein. The elongation process is subject to regulation [92]. For instance, phosphorylation of the eukaryotic elongation factor eEF2 by the calcium- and calmodulindependent kinase CaMKII results in inhibition of translation [92-94]. Interestingly, NMDA receptor activation by sensory stimulation in the superior colliculi of young rats results, within minutes, in enhanced translation of $\alpha \mathrm{CaM}-$ KII, whereas total protein synthesis is reduced through phosphorylation of eEF2 [95, 96]. Inhibiting elongation may permit less efficiently initiated transcripts to become translated. Also, it may allow the translation of a new set of transcripts by removing actively translating transcripts from ribosomes [95]. Translational control through phospho-eEF2 affects general elongation rates and is not directly dependent on the nucleotide sequence of the mRNA. In the following sections we will take a look at how the 5'- and 3'-UTRs control protein synthesis rate through specific sequence motifs.

\section{mRNA Stability}

The rate of protein synthesis depends on the concentration and the translatability of the mRNA, both of which are actively controlled by the cell. Steady state cytoplasmic mRNA levels are determined by the balance between production and decay. The rate with which cytoplasmic mRNAs are produced depends on many steps involved in gene transcription and pre-mRNA processing, as described above. The decay of cellular mRNAs is also highly regulated and for many proteins, mRNA stability appears to be a major determinant of protein synthesis rate [97]. The half-life of mammalian mRNAs can vary from minutes to days, affording differences in cellular mRNA concentration spanning many orders of magnitude.

A variety of nucleotide motifs or 'cis-acting elements' have been characterized in mRNAs that recruit specific (de-)stabilizing RNA-binding proteins. Although these elements can be found anywhere in the mRNA, most stability controlling mechanisms seem to target the 3'-UTR (fig. 3). Notable exceptions are the extremely labile mRNAs that encode the immediate early genes c-fos and c-myc [98-101], and the mRNA for the cytokine interleukine-2 (IL-2) [102], where stability is controlled by elements in the coding region and $5^{\prime}$-UTR. 


\section{Endonuclease-Mediated Decay}

Cytoplasmic mRNAs are protected from degradation on both ends: at the 5 -end by the cap structure and at the 3 -end by the poly-A tail $[99,103]$. Whereas cap-removal has been best described in yeast, deadenylation of the poly-A tail appears to be a critical early event in the degradation of many mammalian mRNAs $[99,104]$. However, small subsets of mRNAs can be attacked by endonucleases, which cleave internally at specific elements in the 5'-UTR, coding region or 3'-UTR [105].

\section{AU-Rich Elements}

Several stability-determining elements have been described to reside in the 3'-UTR of mRNAs. The best characterized of these are the AU-rich elements (AREs), whose presence destabilizes their mRNA. AREs control mRNA stability by binding a large and growing number of specific protein factors that either stimulate or inhibit decay $[99,104,105]$. Many of these proteins are expressed exclusively in the nervous system. A variety of signal transduction pathways $\left(\mathrm{Ca}^{2+}\right.$, PKC, MAPK, JNK kinase, p38) regulate mRNA stability through phosphorylation of these stability factors [106].

\section{Iron Responsive Elements}

Whereas AREs are found in a large number of shortlived mRNAs encoding proto-oncogenes, cytokines and transcription factors [106], examples of highly specialized elements exists as well. One example is the so-called 'iron responsive element' (IRE), a short hairpin sequence found in the 3'-UTR of the transferrin receptor where it regulates mRNA stability, and the 5'-UTR of ferritin mRNA, where it controls translation initiation [99, 104, 105]. Two RNA-binding proteins (IRP1 and IRP2) selectively bind to the IRE hairpin structure and mediate their effect. This mechanism appears to have developed exclusively for iron metabolism. However, recently evidence was found for the presence of an IRE element in the 5'-UTR of the amyloid precursor protein implicated in Alzheimer's disease [107, 108].

\section{Poly-Pyrimidine Tracks}

Another class of stability control elements found in 3'-UTRs of certain mRNAs (insulin, tyrosine hydroxylase, MARCKS and CD154) is characterized by a polypyrimidine track (CU), a CU-rich region containing short repetitive sequences. The CU-rich elements recruit various factors, that (de-)stabilize the mRNA, including pyrimidine binding protein, $\mathrm{HuD}$ and $\mathrm{HuR}$ [109-114].

Roles of NMDA Receptor UTRs

\section{NMDA Receptors}

How important is mRNA stability for the regulation of NMDA receptor expression levels? There are currently no published data that allow us to answer this question firmly. However, the approximately 900-nucleotide-long 3'UTR of NMDA receptor NR1 subunit contains two regions (390 and $250 \mathrm{nt}$ long) which are highly conserved between mouse and human (fig. 4). In fact, the first 100 bases of the 3'-UTR are perfectly conserved. This highly significant homology suggests that the 3'-UTR plays an important biological role. In addition to regulating mRNA stability, the 3'-UTR also mediates mRNA transport and controls translation efficacy (discussed below). Whether any of these control mechanisms are relevant for NR1 will need to be investigated. Although the NR1 3'-UTR does not appear to contain any of the known stability elements (ARE, IRE, poly-CU), a critical role in mRNA stability cannot be ruled out since highly specialized mechanisms do exist. Interestingly, the strictly conserved first 100 nucleotides are predicted to form a stable, long hairpin loop (fig. 5).

\section{Translation Efficacy}

Presence of a stable mRNA in the cytoplasm is required for high level protein expression, but it is not sufficient. Translation of cytoplasmic mRNAs can be inhibited or even completely blocked. Like pre-mRNA processing discussed above, mRNA translation is a complex, multi-step process that is highly regulated. A remarkably diverse number of mechanisms exist, which cells can use to control translation rates over a wide range. A number of excellent reviews have appeared recently, where many of the details can be found [115-117]. Translation involves three distinct phases: initiation [116], elongation [118] and termination [119]. Whereas elongation is controlled by phosphorylation of eEF2, as described above, initiation is the rate-limiting step for most mRNAs [120]. As a result, elaborate schemes have evolved to control the efficiency of translation initiation [120].

\section{Translation Initiation}

According to the 'scanning model' of mammalian translation, formulated by Marilyn Kozak in the early 80 s, the mRNA molecule is scanned by the $40 \mathrm{~S}$ ribosome in the $5^{\prime}$ to $3^{\prime}$ direction to locate the AUG initiation codon, where protein synthesis is initiated $[122,123]$. The $40 \mathrm{~S}$ subunit is part of an initiation complex containing over ten components, including the methionine-contain- 


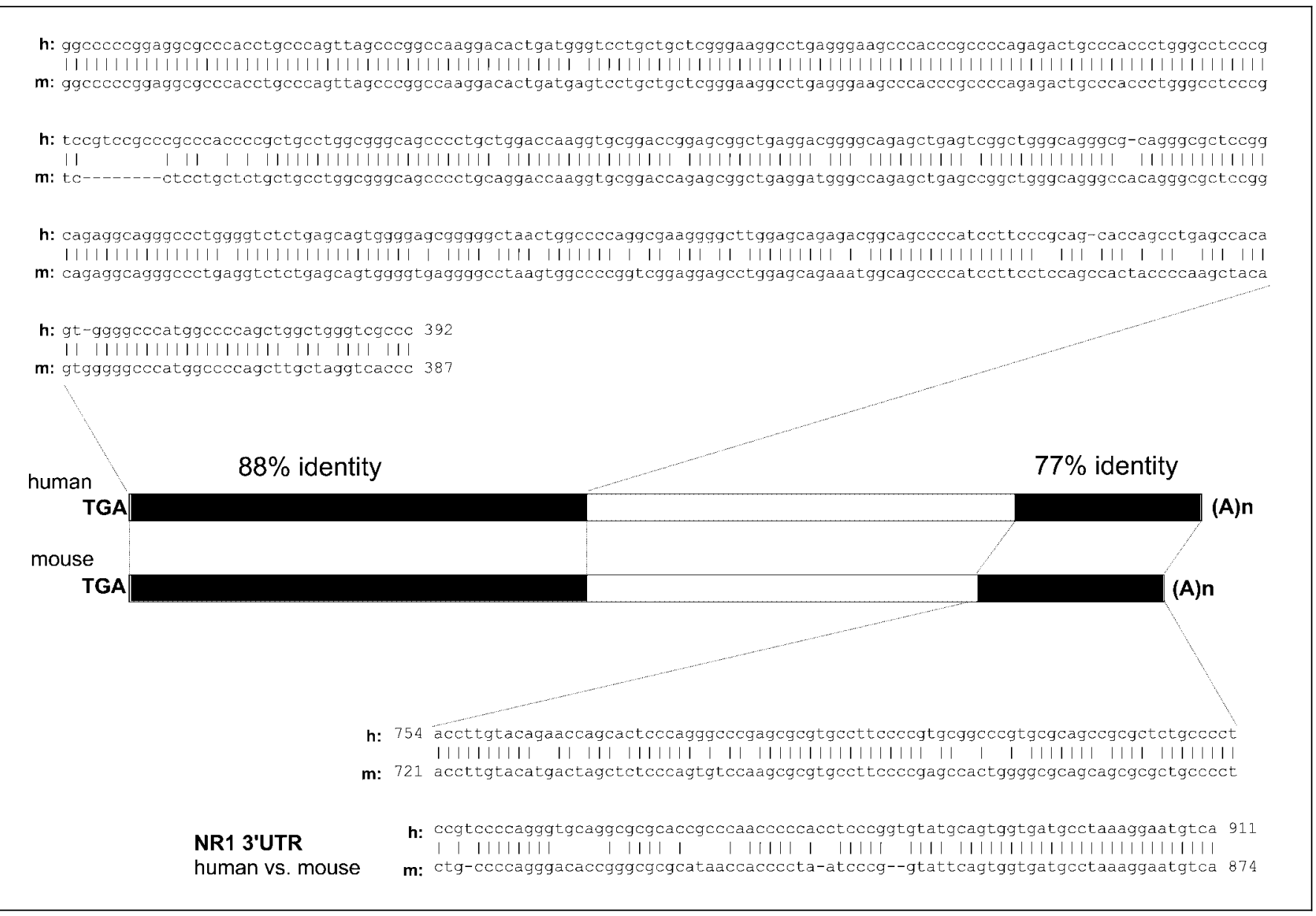

Fig. 4. Conserved elements in the NR1 3'-UTR. The mouse and human NMDA receptor NR1 3'-UTR sequences were aligned using the NCBI Pairwise Blast algorithm (http://www.ncbi.nlm.nih.gov/blast/bl2seq/bl2.html), which revealed two elements with significant homology.

Fig. 5. Secondary structure of the NR1 3'UTR. The structure of the first 100 nucleotides of the 3'-UTR of the human and mouse NMDA receptor NR1 subunit (which are perfectly conserved, see fig. 4) was predicted using Mfold [149].

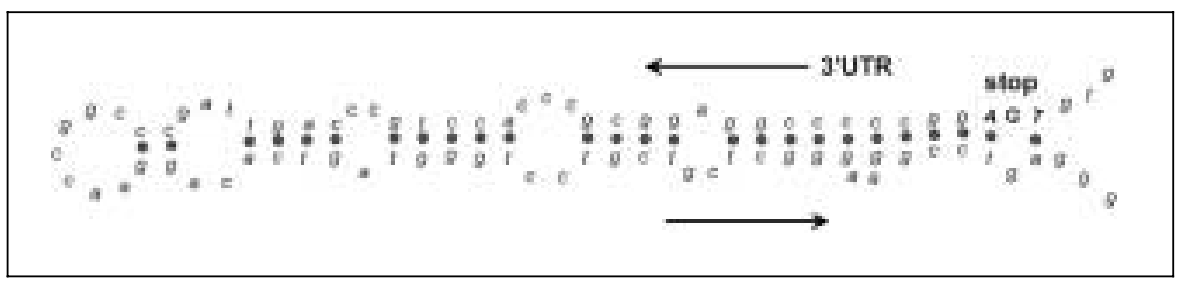

ing initiator-tRNA (Met-tRNAi), a cap-binding protein (eIF4E), an RNA helicase (eIF2A), a scaffolding protein (eIF4G), and other initiation factors. The complex is assembled at the $5^{\prime}$-end through the eIF4E-cap interaction and linearly moves along the $5^{\prime}$-UTR until the initiation codon is identified by base-pairing with the anti-codon of the Met-tRNAi. Here the complex is partly disassembled and the $60 \mathrm{~S}$ ribosomal subunit is recruited to form a translationally competent 80 S complex [116].

Any mechanism that interferes with efficient scanning of the 5'-UTR is expected to affect translational efficacy. For instance, strong secondary structures in long GC-rich 5'-UTRs would slow down scanning by inducing a requirement for RNA-helicase activity. Strong secondary 
structures in the $5^{\prime}$-UTR have been reported to severely reduce translation efficacy of the NMDA receptor NR2A subunit [124]. From this it may be concluded that efficacy-determining elements will be exclusively found in the 5'-UTR. This is however not the case: several translational control mechanisms have been described for the 3'-UTR that do not operate by altering mRNA stability. This is made possible by the action of the poly-A binding protein, which binds simultaneously to the poly-A tail and the eIEF4G scaffold in the initiation complex. This interaction circularizes the mRNA molecule and allows the 3 -UTR to affect initiation efficacy $[116,125]$. Next, we will briefly discuss some of the known elements controlling translational efficacy.

\section{Cytoplasmic Polyadenylation Element (3'-UTR)}

Studies of translation regulation in oocytes have yielded important insights in translation control mechanisms that also operate outside early development. Maternal mRNAs in oocytes are translationally repressed until fertilization. One mechanism employs the 'cytoplasmic polyadenylation element', which can affect translation efficacy by controlling the length of the poly-A tail (described above) or by recruiting masking proteins that block translation [126]. Cytoplasmic polyadenylation has already been shown to be operational in neurons, where it controls translational efficacy of $\alpha$ CaMKII mRNA [90]. Whether CPE-based masking mechanisms also function outside oocyte development remains to be seen. The 3'-UTRs of mRNAs encoding NMDA receptor subunits do not contain any known CPE elements.

\section{Micro RNAs (3'-UTR)}

An exciting new finding is the discovery of translation factors which are not proteins, but tiny RNA molecules termed 'microRNAs' (miRNAs) [117]. Originally discovered in Caenorhabditis elegans [127, 128], a large and growing number of miRNAs are now being described for several species $[129,130]$. They appear to affect expression levels of the genes they target by binding to complementary sequences in the 3'-UTR, resulting in either translational repression or mRNA cleavage [129, 131]. Since the target genes and mechanisms of action for most miRNAs remain to be identified, it is too early to tell whether NMDA receptors are controlled in this fashion.

\section{Upstream Open Reading Frame (5'-UTR)}

According to the scanning hypothesis, the initiation complex moving along the 5'-UTR will halt at the first UAG and initiate translation. However, many genes are known to have spurious AUG codons in their 5'-UTR, upstream from the initiation codon associated with the long ORF encoding the protein. Such upstream AUGs (uAUGs) give rise to short, upstream ORFs (uORFs), encoding peptides which usually have no known function. Translation of the correct ORF still occurs in mRNAs containing uAUGs, although usually with reduced efficacy. Various models have been proposed for how uAUGs are dealt with [121], including 'leaky scanning' where the scanning initiation complex bypasses the uAUGs, and 'reinitiation' of the ribosome following translation of the uORF. Alternatively, the uAUGs may be entirely bypassed by an internal ribosome entry sites (IRES) mechanism that does not involve scanning at all.

\section{$\operatorname{IRES}\left(5^{\prime}-U T R\right)$}

IRES were originally discovered in the RNA genome of picorna viruses [132]. They fold into unique secondary and tertiary structures immediately preceding the start codon, which are able to directly recruit an initiation complex, thereby circumventing the need for scanning. This mechanism is cap-independent, and is insensitive to strong secondary structures or uAUGs that precede the IRES, thereby providing a possible explanation for the efficient translation sometimes seen in long, structured uAUG-rich eukaryotic mRNAs. The evidence for IRES translation in RNA viruses is incontrovertible, and a sizable literature exists supporting the idea that a subset of cellular mRNAs employs some kind of IRES mechanism for translation [133, 134]. However, a dissenting view challenging the evidence for the existence of cellular IRES mechanisms has been put forward [122]. A comment with counter-arguments and reply [135] makes for very interesting reading.

The main problem associated with cellular IRES studies is the use of bi-cistronic plasmids, where a $5^{\prime}$-UTR of interest is cloned between two ORFs, each encoding a different reporter. Activity of the second reporter is then taken as evidence for the existence of a functional IRES in the tested 5'-UTR. However, there are several alternative explanations for activity of the second ORF: the intervening sequence may display weak promoter activity, direct aberrant splicing of the pre-mRNA or even induce cleavage or breakage of the mature mRNA. Each of these processes can produce small amounts of mRNA containing only the second ORF. The weak translational activity of this improperly processed mRNA may be considered sufficient, since only weak activity is expected for the putative IRES: even authentic viral IRES sequences often perform poorly in bi-cistronic vectors, being several-fold less 


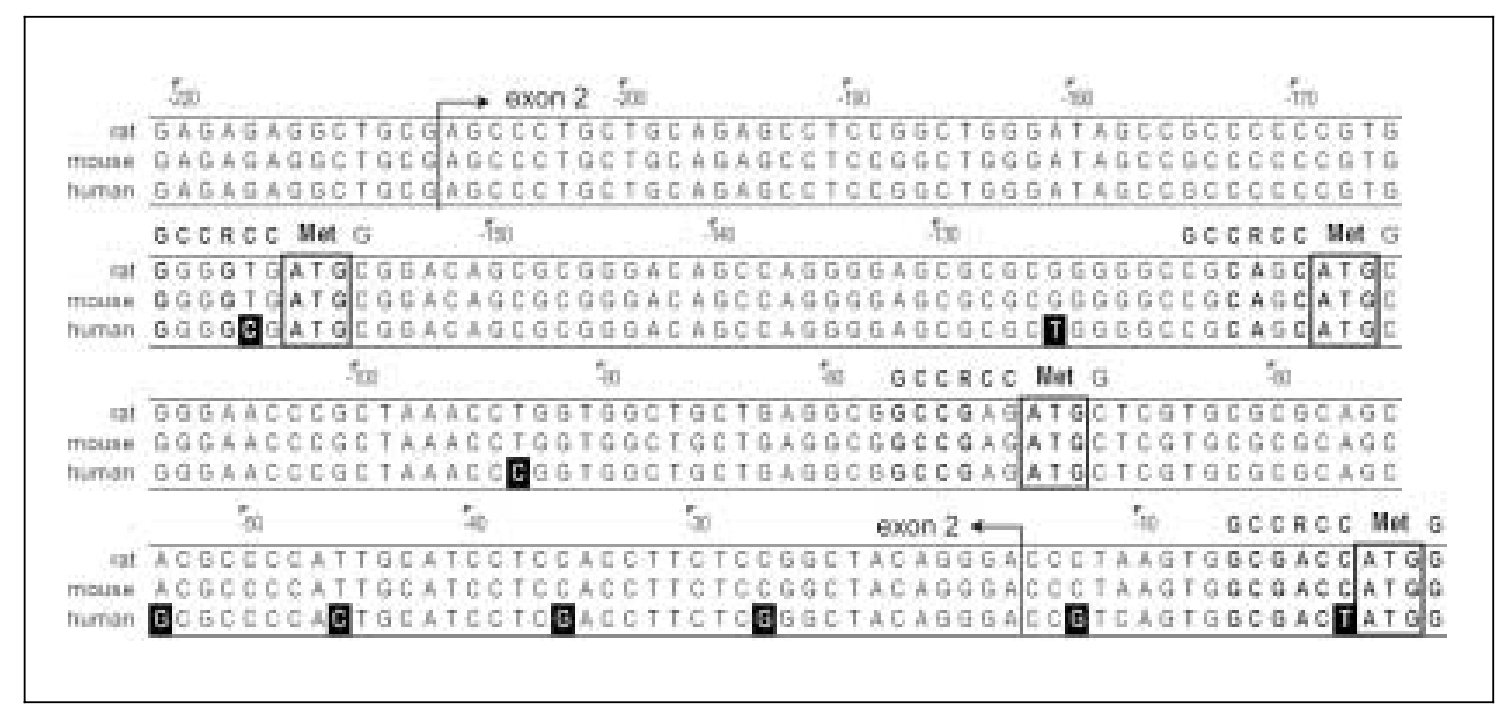

Fig. 6. Homology and uAUGs in the NR2A 5'-UTR. Alignment of the 222 nucleotides immediately preceding the start codon for the rat, mouse and human 5'-UTR of NR2A. uAUGs are boxed and Kozak consensus sequences [150] are given above each AUG ( $\mathrm{R}$ indicates $\mathrm{A}$ or $\mathrm{G}$ ). Nucleotides conforming to the consensus are in bold. Whereas the actual start codon has a near perfect context, the uAUGs become less optimal the further away they are from the start codon [124].

efficient than optimal cap-dependent translation. Controls using unrelated or mutated intervening sequences are not adequate, since all three alternative mechanisms are sequence dependent.

The 5'-UTR of the NMDA receptor NR2A subunit supports translation of the second ORF when placed in a bi-cistronic reporter [H.M.A. VanDongen, unpubl. obs.]. However, given the reservations outlined above, better experimental approaches will need to be employed to rigidly test whether the NR2A subunit indeed contains a functional IRES element.

\section{NMDA Receptors}

Long 5'-UTRs containing multiple uAUGs are quite rare and have thus far only been found in mRNAs encoding proto-oncogenes, transcription/growth factors, and their receptors, whose translation needs to be carefully controlled [121]. Interestingly, NMDA receptor subunits are part of this exclusive group of genes, since their mRNAs display 5'-UTRs that are unusually long, are highly conserved between species, and contain multiple uAUGs (table 1). Of the five NMDA receptor genes, only NR2C does not contain any uAUGs. The lengths of the 5'-UTRs in table 1 are based on published cDNA sequences, which are often incomplete at their $5^{\prime}$-UTR. The only exception is the $1568 \mathrm{nt}$ long NR2A 5'-UTR, which was derived from the first three exons of the recently published genomic sequence [136]. The longest published cDNA-derived 5'-UTR for NR2A is much shorter (222 nts), suggesting that other NMDA receptor subunits may also have substantially longer 5'-UTRs than indicated by table 1 .

The 5'-UTR of the NR2B subunit is subject to alternative splicing, as illustrated by figure 2 . Translational efficacies have not yet been characterized for the different splice variants. If the NR2B mRNA is translated by 'leaky scanning', then the shortest isoform should perform substantially better, since it has fewer than half the number of AUGs. Part of the 5'-UTR of NR2A is highly conserved between species (fig. 6). This 222-nucleotide-long region immediately precedes the start codon and includes all of exon 2 (fig. 6). We characterized a mouse cDNA clone [137] that is slightly longer ( $278 \mathrm{nt})$, and found that translation of the corresponding mRNA was inhibited more than 100-fold, in both Xenopus oocytes and rabbit reticulocyte lysates [124]. Interestingly, mutation of 2 of the 5 uAUGs (uAUG No. 1 and No. 3 in fig. 6) either had not effect or only modestly enhanced translation. If these mRNAs are translated through 'leaky initiation', then the scanning ribosome very efficiently ignores these two uAUGs. 
Table 1. Upstream AUGs and ORFs in NMDA receptor $5^{\prime}$-UTRs

\begin{tabular}{llccc}
\hline Subunit & Species & Length 5'-UTR & uAUGs & uORFs \\
\hline NR10 & Human & 1,095 & 6 & 4 \\
NR2A & Rat & 1,568 & 15 & 11 \\
NR2B & Mouse & 870 & 10 & 8 \\
NR2C & Rat & 523 & 0 & 0 \\
NR2D & Rat & 739 & 9 & 7 \\
\hline
\end{tabular}

\section{mRNA Trafficking and Dendritic Translation}

One unique advantage that translation has over transcription, as a mechanism to regulate functional expression of proteins, is that it can be performed locally, at any subcellular localization (except the nucleus). In the nervous system this is a key property, since the ability of individual synapses to alter their efficacy based on recent activity is the current molecular model for learning and memory. Synapses are localized in the neuronal soma as well as in distal dendrites, many hundreds of microns away from the soma, where the bulk of protein synthesis takes place. Electron-microscopy has shown that polysomes, ER, Golgi-like structures, and many components of the translation apparatus are closely associated with distal synapses [138-141]. Local synaptic protein synthesis requires that a subset of mRNAs is trafficked from the soma to distal dendrites. Two genes for which mRNA trafficking has been well characterized are beta-actin and myelin-basic protein [142, 143]. Targeting of these mRNAs is mediated by a region in the 3 '-UTR in close proximity to the stop codon, referred to as a 'zip code' [144].
In the central nervous system, a subset of cellular mRNAs is targeted to distal dendrites and locally translated $[145,146]$. Thus far, convincing experimental evidence for dendritic translation is limited to soluble proteins. However, the fact that NMDA receptor proteins in distal dendrites can appear in minutes following appropriate synaptic input has been used as an argument for local protein synthesis: this time frame appears too short to allow trafficking of new receptor proteins from the soma [90, 147, 148]. The sequence conservation, length and proximity to the stop codon are all consistent with the hypothesis that the first 100 nucleotides of the NR1 3'UTR (fig. 5) encodes a zipcode. However, there is no experimental evidence to date to support this idea.

\section{Conclusions}

An overview was provided of the many travails in which mRNA molecules take place, after they are synthesized during gene transcription. Elaborate processing in the nucleus is followed by export to the cytosol, optional targeting to distal parts of the cell, recognition by the translational apparatus, scanning of the 5'-UTR, translation initiation, elongation and termination, and finally, regulated decay. Each of the individual steps is carefully controlled, providing many opportunities for regulation. This review has focused on control mechanisms encoded by elements in the untranslated regions of the mRNA, and where possible, discussed implications for regulating expression of NMDA receptors. Whereas the structure and sequence conservation of the UTRs suggest that translational control may play a critical role in regulating NMDA receptor expression, experimental evidence for this hypothesis remains scarce.

\section{References}

1 Dingledine R, Borges K, Bowie D, Traynelis SF: The glutamate receptor ion channels. Pharmacol Rev 1999;51:7-61.

2 Nowak L, Bregestovski P, Ascher P, Herbert A, Prochiantz A: Magnesium gates glutamate-activated channels in mouse central neurones. Nature 1984;307:462-465.

3 Mayer ML, Westbrook GL, Guthrie PB: Voltage-dependent block by $\mathrm{Mg}$ of NMDA responses in spinal cord neurones. Nature 1984; 309:261-263.

4 MacDermott AB, Mayer ML, Westbrook GL, Smith SJ, Barker JL: NMDA-receptor activation increases cytoplasmic calcium concentration in cultured spinal cord neurones. Nature 1986;321:519-522.
5 Traynelis SF: pH Modulation of ligand-gated ion channels; in Kaila K, Ransom BR (eds): pH and Brain Function. New York, Wiley-Liss, Inc, 1998, pp 417-446.

6 Lipton SA, Rayudu PV, Choi YB, Sucher NJ, Chen HS: Redox modulation of the NMDA receptor by NO-related species. Prog Brain Res 1998;118:73-82.

7 Lipton SA, Choi YB, Takahashi H, Zhang D, Li W, Godzik A, Bankston LA: Cysteine regulation of protein function - as exemplified by NMDA-receptor modulation. Trends Neurosci 2002;25:474-480.
8 Low CM, Zheng F, Lyuboslavsky P, Traynelis SF: Molecular determinants of coordinated proton and zinc inhibition of N-methyl-Daspartate NR1/NR2A receptors. Proc Natl Acad Sci USA 2000;97:11062-11067.

9 Omelchenko IA, Nelson CS, Allen CN: Lead inhibition of N-methyl-D-aspartate receptors containing NR2A, NR2C and NR2D subunits. J Pharmacol Exp Therap 1997;282:14581464.

10 Williams K, Romano C, Dichter MA, Molinoff PB: Modulation of the NMDA receptor by polyamines. Life Sci 1991;48:469-498. 
11 Rock DM, Macdonald RL: Polyamine regulation of N-methyl-D-aspartate receptor channels. Ann Rev Pharmacol Toxicol 1995;35: 463-482.

12 Vallano ML: Developmental aspects of NMDA receptor function. Crit Rev Neurobiol 1998;12: 177-204.

13 Constantine-Paton M: The plastic brain. Neurobiol Disease 2000; 7:515-519.

14 Malenka RC, Nicoll RA: NMDA-receptor-dependent synaptic plasticity: Multiple forms and mechanisms. Trends Neurosci 1993;16: 521-527.

15 Bear MF: NMDA-receptor-dependent synaptic plasticity in the visual cortex. Prog Brain Res 1996;108:205-218.

16 Ikonomidou C, Bosch F, Miksa M, Bittigau P, Vockler J, Dikranian K, Tenkova TI, Stefovska V, Turski L, Olney JW: Blockade of NMDA receptors and apoptotic neurodegeneration in the developing brain. Science 1999;283:70-74

17 Mody I, MacDonald JF: NMDA receptor-dependent excitotoxicity: the role of intracellular $\mathrm{Ca}^{2+}$ release. Trends Pharmacol Sci 1995;16: 356-359.

18 Kemp JA, McKernan RM: NMDA receptor pathways as drug targets. Nat Neurosci 2002 5(suppl):1039-1042.

19 Newcomer JW, Krystal JH: NMDA receptor regulation of memory and behavior in humans. Hippocampus 2001;11:529-542.

20 Rison RA: Schizophrenia and N-methyl- $D$-aspartate receptors: evolutionary adaptations from malfunctioning molecules? Neuropsychiatry, Neuropsychol Behav Neurol 1998;11: 236-240.

21 Duncan GE, Zorn S, Lieberman JA: Mechanisms of typical and atypical antipsychotic drug action in relation to dopamine and NMDA receptor hypofunction hypotheses of schizophrenia. Mol Psychiatry 1999;4:418428.

22 Jentsch JD, Roth RH: The neuropsychopharmacology of phencyclidine: from NMDA receptor hypofunction to the dopamine hypothesis of schizophrenia. Neuropsychopharmacology 1999;20:201-225.

23 Chatterton JE, Awobuluyi M, Premkumar LS, Takahashi H, Talantova M, Shin Y, Cui J, Tu S, Sevarino KA, Nakanishi N, Tong G, Lipton SA, Zhang D: Excitatory glycine receptors containing the NR3 family of NMDA receptor subunits. Nature 2002;415:793-798.

24 Cull-Candy S, Brickley S, Farrant M: NMDA receptor subunits: diversity, development and disease. Curr Opin Neurobiol 2001;11:327335 .

25 Sucher NJ, Awobuluyi M, Choi YB, Lipton SA NMDA receptors: From genes to channels Trends Pharmacol Sci 1996;17:348-355.

26 Zimmer M, Fink TM, Franke Y, Lichter P, Spiess J: Cloning and structure of the gene encoding the human N-methyl-D-aspartate receptor (NMDAR1). Gene 1995;159:219-223.

27 Suchanek B, Seeburg PH, Sprengel R: Tissue specific control regions of the N-methyl-D aspartate receptor subunit NR2C promoter. Biol Chem 1997:378:929-934.
28 Richter M, Suau P, Ponte I: Sequence and analysis of the $5^{\prime}$ flanking and $5^{\prime}$ untranslated regions of the rat N-methyl-D-aspartate receptor 2A gene. Gene 2002;295:135-142.

29 Klein M, Pieri I, Uhlmann F, Pfizenmaier K, Eisel U: Cloning and characterization of promoter and 5'-UTR of the NMDA receptor subunit epsilon 2: Evidence for alternative splicing of 5'-non-coding exon. Gene 1998;208:259269.

30 Bai G, Kusiak JW: Cloning and analysis of the 5 ' flanking sequence of the rat $N$-methyl- $D$ aspartate receptor 1 (NMDAR1) gene. Biochim Biophys Acta Bio-Membr 1993;1152: 197-200

31 Bai G, Kusiak JW: Functional analysis of the proximal 5'-flanking region of the N-methyl- $D$ aspartate receptor subunit gene, NMDAR1. J Biol Chem 1995;270:7737-7744.

32 Pieri I, Klein M, Bayertz C, Gerspach J, van der PA, Pfizenmaier K, Eisel U: Regulation of the murine NMDA-receptor-subunit NR2C promoter by $\mathrm{Spl}$ and fushi tarazu factor 1 (FTZ-F1) homologues. Eur J Neurosci 1999; 11:2083-2092.

33 Watanabe $\mathrm{T}$, Inoue $\mathrm{S}$, Hiroi $\mathrm{H}$, Orimo $\mathrm{A}, \mathrm{Mu}-$ ramatsu $\mathrm{M}$ : NMDA receptor type $2 \mathrm{D}$ gene as target for estrogen receptor in the brain. Mol Brain Res 1999;63:375-379.

34 Vasudevan N, Kai HK, Inoue S, Muramatsu M, Dfaff D: Isoform specificity for oestrogen receptor and thyroid hormone receptor genes and their interactions on the NR2D gene promotor. J Neuroendocrinol 2002;14:836-842.

35 Ozaki M, Sasner M, Yano R, Lu HS, Buonanno A: Neuregulin-beta induces expression of an NMDA-receptor subunit. Nature 1997;390: 691-694.

36 Bai G, Kusiak JW: Nerve growth factor up-regulates the N-methyl- $D$-aspartate receptor subunit 1 promoter in PC12 cells. J Biol Chem 1997;272:5936-5942.

37 Mao X, Moerman AM, Barger SW: Neuronal kappa B-binding factors consist of Sp1-related proteins. Functional implications for autoregulation of N-methyl- $D$-aspartate receptor-1 expression. J Biol Chem 2002;277:4491144919.

38 Liu A, Prenger MS, Norton DD, Mei L, Kusiak JW, Bai G: Nerve growth factor uses Ras/ERK and phosphatidylinositol 3-kinase cascades to up-regulate the N-methyl- $D$-aspartate receptor 1 promoter. J Biol Chem 2001;276:4537245379.

39 Krainc D, Bai G, Okamoto S, Carles M, Kusiak JW, Brent RN, Lipton SA: Synergistic activation of the N-methyl- $D$-aspartate receptor subunit 1 promoter by myocyte enhancer factor $2 \mathrm{C}$ and Sp1. J Biol Chem 1998;273:26218-26224.

40 Desai A, Turetsky D, Vasudevan K, Buonanno A: Analysis of transcriptional regulatory sequences of the N-methyl- $D$-aspartate receptor $2 \mathrm{~A}$ subunit gene in cultured cortical neurons and transgenic mice. J Biol Chem 2002;277: 46374-46384.

41 Casado M, Lopez-Guajardo A, Mellstrom B, Naranjo JR, Lerma J: Functional N-methyl- $D$ aspartate receptors in clonal rat phaeochromocytoma cells. J Physiol 1996;490:391-404.
42 Resink A, Villa M, Benke D, Mohler H, Balazs $\mathrm{R}$ : Regulation of the expression of NMDA receptor subunits in rat cerebellar granule cells: effect of chronic $\mathrm{K}^{+}$-induced depolarization and NMDA exposure. J Neurochem 1995;64: 558-565.

43 Leclerc CL, Chi CL, Awobuluyi M, Sucher NJ: Expression of N-methyl- $D$-aspartate receptor subunit mRNAs in the rat pheochromocytoma cell line PC12. Neurosci Lett 1995;201:103106.

44 Husi H, Ward MA, Choudhary JS, Blackstock WP, Grant SG: Proteomic analysis of NMDA receptor-adhesion protein signaling complexes. Nat Neurosci 2000;3:661-669.

45 Boeckers TM, Bockmann J, Kreutz MR, Gundelfinger ED: ProSAP/Shank proteins - a family of higher order organizing molecules of the postsynaptic density with an emerging role in human neurological disease. J Neurochem 2002;81:903-910.

46 Hardingham GE, Bading $\mathrm{H}$ : The Yin and Yang of NMDA receptor signalling. Trends Neurosci 2003;26:81-89.

47 Carroll RC, Zukin RS: NMDA-receptor trafficking and targeting: implications for synaptic transmission and plasticity. Trends Neurosci 2002;25:571-577.

48 Barria A, Malinow R: Subunit-specific NMDA receptor trafficking to synapses. Neuron 2002; 35:345-353.

49 Wenthold RJP: Trafficking of NMDA receptors. Annu Rev Pharmacol Toxicol 2003;43: 335-358.

50 Huh KH, Wenthold RJ: Turnover analysis of glutamate receptors identifies a rapidly degraded pool of the N-methyl- $D$-aspartate receptor subunit, NR1, in cultured cerebellar granule cells. J Biol Chem 1999;274:151-157.

51 Dunah AW, Standaert DG: Dopamine D1 receptor-dependent trafficking of striatal NMDA glutamate receptors to the postsynaptic membrane. J Neurosci 2001;21:5546-5558.

52 Lan JY, Skeberdis VA, Jover T, Grooms SY, Lin Y, Araneda RC, Zheng X, Bennett MV, Zukin RS: Protein kinase $C$ modulates NMDA receptor trafficking and gating. Nature Neurosci 2001;4:382-390.

53 Skeberdis VA, Lan J, Zheng X, Zukin RS, Bennett MV: Insulin promotes rapid delivery of $\mathrm{N}$ methyl- $D$-aspartate receptors to the cell surface by exocytosis. Proc Natl Acad Sci USA 2001; 98:3561-3566.

54 Grosshans DR, Clayton DA, Coultrap SJ, Browning MD: LTP leads to rapid surface expression of NMDA but not AMPA receptors in adult rat CA1. Nat Neurosci 2002;5:27-33.

55 Neugebauer KM: On the importance of being co-transcriptional. J Cell Sci 2002;115:38653871 .

56 Goldstrohm AC, Greenleaf AL, Garcia-Blanco MA: Co-transcriptional splicing of pre-messenger RNAs: Considerations for the mechanism of alternative splicing. Gene 2001;277:31-47.

57 Howe KJ: RNA polymerase II conducts a symphony of pre-mRNA processing activities. Biochim Biophys Acta 2002;1577:308-324. 
58 Nilsen TW: RNA-RNA interactions in nuclear pre-mRNA splicing; in Simons RW GrunbergManago M (eds): RNA Structure and Function. Cold Spring Harbor Laboratory Press, 1998.

59 Krecic AM, Swanson MS: hnRNP complexes: Composition, structure, and function. Curr Opin Cell Biol 1999;11:363-371.

60 Reed R, Magni K: A new view of mRNA export: Separating the wheat from the chaff. Nat Cell Biol 2001;3:E201-E204.

61 Singh OP: Functional diversity of hnRNP proteins. Indian J Biochem Biophys 2001;38:129_ 134.

62 Izaurralde E, Lewis J, McGuigan C, Jankowska M, Darzynkiewicz E, Mattaj IW: A nuclear cap binding protein complex involved in premRNA splicing. Cell 1994;78:657-668.

63 Wilusz CJ, Wormington M, Peltz SW: The capto-tail guide to mRNA turnover. Nat Rev Mol Cell Biol 2001;2:237-246.

64 O'Mullane L, Eperon IC: The pre-mRNA 5 cap determines whether U6 small nuclear RNA succeeds U1 small nuclear ribonucleoprotein particle at 5' splice sites. Mol Cell Biol 1998;18: 7510-7520.

65 Moy TI, Silver PA: Requirements for the nuclear export of the small ribosomal subunit. J Cell Sci 2002;115:2985-2995.

66 Lei EP, Silver PA: Intron status and 3'-end formation control cotranscriptional export of mRNA. Genes Dev 2002;16:2761-2766.

67 Zarudnaya MI, Kolomiets IM, Hovorun DM: What nuclease cleaves pre-mRNA in the process of polyadenylation? IUBMB Life 2002; 54: 27-31.

68 Manley JL: A complex protein assembly catalyzes polyadenylation of mRNA precursors. Curr Opin Genet Dev 1995;5:222-228.

69 Seeburg PH: A-to-I editing: New and old sites, functions and speculations. Neuron 2002;35: 17-20.

70 Rosenthal JJ, Bezanilla F: Extensive editing of mRNAs for the squid delayed rectifier $\mathrm{K}^{+}$ channel regulates subunit tetramerization. Neuron 2002;34:743-757.

71 Patton DE, Silva T, Bezanilla F: RNA editing generates a diverse array of transcripts encoding squid $\mathrm{Kv} 2 \mathrm{~K}^{+}$channels with altered functional properties. Neuron 1997;19:711-722.

72 Bass BL: RNA editing by adenosine deaminases that act on RNA. Annu Rev Biochem 2002;71:817-846.

73 Morse DP, Aruscavage PJ, Bass BL: RNA hairpins in noncoding regions of human brain and Caenorhabditis elegans mRNA are edited by adenosine deaminases that act on RNA. Proc Natl Acad Sci USA 2002;99:7906-7911.

74 Seeburg PH: The role of RNA editing in controlling glutamate receptor channel properties. J Neurochem 1996;66:1-5.

75 Brusa R, Zimmerman F, Koh D-S, Feldmeyer D, Gass P, Seeburg PH, Sprengel R: Earlyonset epilepsy and postnatal lethality associated with an editing-deficient GluR-B allele in mice. Science 1995;270:1677-1680.

76 Jurica MS, Moore MJ: Capturing splicing complexes to study structure and mechanism. Methods 2002;28:336-345.
77 Ladd AN, Cooper TA: Finding signals that regulate alternative splicing in the post-genomic era. Genome Biol 2002;3:reviews8.1-8.16.

78 Smith CW, Valcarcel J: Alternative pre-mRNA splicing: The logic of combinatorial control. TIBS 2000;25:381-388.

79 Singh R: RNA-protein interactions that regulate pre-mRNA splicing. Gene Exp 2002;10: 79-92.

80 Modrek B, Lee C: A genomic view of alternative splicing. Nat Genet 2003;30:13-19.

81 Grabowski PJ, Black DL: Alternative RNA splicing in the nervous system. Prog Neurobiol 2001;65:289-308.

82 Traynelis SF, Hartley M, Heinemann SF: Control of proton sensitivity of the NMDA receptor by RNA splicing and polyamines. Science 1995;268:873-876

83 Ehlers MD, Tingley WG, Huganir RL: Regulated subcellular distribution of the NR1 subunit of the NMDA receptor. Science 1995;269: 1734-1737.

84 Keene JD: Organizing mRNA export. Nature Genet 2003;33:111-112.

85 Hieronymus H, Silver PA: Genome-wide analysis of RNA-protein interactions illustrates specificity of the mRNA export machinery. Nat Genet 2003;33:155-161.

86 Windgassen $\mathrm{M}$, Krebber H: Identification of Gbp2 as a novel poly(A)+ RNA-binding protein involved in the cytoplasmic delivery of messenger RNAs in yeast. EMBO Rep 2003;4: 278-283.

87 Herold A, Teixeira L, Izaurralde E: Genomewide analysis of nuclear mRNA export pathways in Drosophila. EMBO J 2003;22:24722483.

88 Kendirgi F, Barry DM, Griffis ER, Powers MA, Wente SR: An essential role for hGlel nucleocytoplasmic shuttling in mRNA export. J Cell Biol 2003;160:1029-1040.

89 Richter JD: Cytoplasmic polyadenylation in development and beyond. Microbiol Mol Biol Rev 1999;63:446-456.

90 Wells DG, Dong X, Quinlan EM, Huang YS, Bear MF, Richter JD, Fallon JR: A role for the cytoplasmic polyadenylation element in NMDA receptor-regulated mRNA translation in neurons. J Neurosci 2001;21:9541-9548.

91 Wu L, Wells D, Tay J, Mendis D, Abbott MA, Barnitt A, Quinlan E, Heynen A, Fallon JR, Richter JD: CPEB-mediated cytoplasmic polyadenylation and the regulation of experiencedependent translation of alpha-CaMKII mRNA at synapses. Neuron 1998;21:11291139.

92 Proud CG: Peptide-chain elongation in eukaryotes. Mol Biol Reports 1994;19:161-170.

93 Ryazanov AG, Rudkin BB, Spirin AS: Regulation of protein synthesis at the elongation stage. New insights into the control of gene expression in eukaryotes. FEBS Lett 1991;285:170175.

94 Ryazanov AG, Spirin AS: Phosphorylation of elongation factor 2:A key mechanism regulating gene expression in vertebrates. New Biol 1990;2:843-850.
95 Scheetz AJ, Nairn AC, Constantine-Paton M: NMDA receptor-mediated control of protein synthesis at developing synapses. Nat Neurosci 2000;3:211-216.

96 Scheetz AJ, Nairn AC, Constantine-Paton M: $\mathrm{N}$-methyl- $D$-aspartate receptor activation and visual activity induce elongation factor-2 phosphorylation in amphibian tecta: A role for $\mathrm{N}$-methyl- $D$-aspartate receptors in controlling protein synthesis. Proc Natl Acad Sci USA 1997;94:14770-14775.

97 Mitchell P, Tollervey D: mRNA stability in eukaryotes. Curr Opin Genet Dev 2000;10: 193-198.

98 Wisdom $\mathrm{R}$, Lee $\mathrm{W}$ : The protein-coding region of c- $m y c$ mRNA contains a sequence that specifies rapid mRNA turnover and induction by protein synthesis inhibitors. Genes Dev 1991; 5:232-243.

99 Guhaniyogi J, Brewer G: Regulation of mRNA stability in mammalian cells. Gene 2001;265:11-23.

100 Dalgleish G, Veyrune JL, Blanchard JM, Hesketh J: mRNA localization by a 145 -nucleotide region of the c-fos 3'-untranslated region. Links to translation but not stability. J Biol Chem 2001;276:13593-13599.

101 Bernstein PL, Herrick DJ, Prokipcak RD, Ross J: Control of c-myc mRNA half-life in vitro by a protein capable of binding to a coding region stability determinant. Genes Dev 1992;6:642-654

102 Chen CY, Gatto-Konczak F, Wu Z, Karin M: Stabilization of interleukin-2 mRNA by the c-Jun NH2-terminal kinase pathway. Science 1998;280:1945-1949.

103 Mitchell P, Tollervey D: mRNA stability in eukaryotes. Curr Opin Genet Dev 2000;10: 193-198.

104 Brennan CM, Steitz JA: HuR and mRNA stability. Cell Mol Life Sci 2003;58:266-277.

105 Hollams EM, Giles KM, Thomson AM, Leedman PJ: MRNA stability and the control of gene expression: Implications for human disease. Neurochem Res 2002;27:957-980.

106 Shim J, Karin M: The control of mRNA stability in response to extracellular stimuli. Molec Cells 2002;14:323-331.

107 Pinero DJ, Hu J, Connor JR: Alterations in the interaction between iron regulatory proteins and their iron responsive element in normal and Alzheimer's diseased brains. Cell Mol Biol 2000;46:761-776.

108 Rogers JT, Randall JD, Cahill CM, Eder PS, Huang X, Gunshin H, Leiter L, McPhee J, Sarang SS, Utsuki T, Greig NH, Lahiri DK, Tanzi RE, Bush AI, Giordano T, Gullans SR: An iron-responsive element type II in the 5'untranslated region of the Alzheimer's amyloid precursor protein transcript. J Biol Chem 2002;277:45518-45528.

109 Wein G, Rossler M, Klug R, Herget T: The $3^{\prime} \mathrm{UTR}$ of the mRNA encoding for the major protein kinase $\mathrm{C}$ substrate MARCKS contains a novel CU-rich element interacting with the mRNA stabilizing factors $\mathrm{HuD}$ and HuR. Eur J Biochem 2003;270:350-365. 
110 Tillmar L, Carlsson C, Welsh N: Control of insulin mRNA stability in rat pancreatic islets. Regulatory role of a 3'-untranslated region pyrimidine-rich sequence. J Biol Chem 2002;277:1099-1106.

111 Tillmar L, Welsh N: Hypoxia may increase rat insulin mRNA levels by promoting binding of the polypyrimidine tract-binding protein (PTB) to the pyrimidine-rich insulin mRNA 3'-untranslated region. Mol Med 2002;8:263-272.

112 Paulding WR, Czyzyk-Krzeska MF: Hypoxia-induced regulation of mRNA stability. Adv Exp Med Biol 2000;475:111-121.

113 Paulding WR, Czyzyk-Krzeska M: Regulation of tyrosine hydroxylase mRNA stability by protein-binding, pyrimidine-rich sequence in the 3 -untranslated region. J Biol Chem 1999;274:2532-2538.

114 Hamilton BJ, Genin A, Cron RQ, Rigby WF: Delineation of a novel pathway that regulates CD154 (CD40 ligand) expression. Mol Cell Biol 2003;23:510-525.

115 Meijer HA, Thomas AA: Control of eukaryotic protein synthesis by upstream open reading frames in the $5^{\prime}$-untranslated region of an mRNA. Biochem J 2002;367:1-11.

116 Mazumder B, Seshadri V, Fox PL: Translational control by the 3'-UTR: The ends specify the means. TIBS 2003;28:91-98.

117 Wilkie GS, Dickson KS, Gray NK: Regulation of mRNA translation by 5'- and 3'UTRbinding factors. Trends Biosci 2003;28:182188.

118 Andersen GR, Nissen P, Nyborg J: Elongation factors in protein biosynthesis. Trends Biosci, in press.

119 Nakamura Y, Ito K: Making sense of mimic in translation termination. Trends Biosci 2003;28:99-105.

120 Sachs AB, Varani G: Eukaryotic translation initiation: there are (at least) two sites to every story. Nat Struct Biol 2003; 7:356-361.

121 Gray NK, Wickens M: Control of translation initiation in animals. Annu Rev Cell Dev Biol 1998;14:399-458.

122 Kozak M: New ways of initiating translation in eukaryotes? Mol Cell Biol 2001;21:18991907.

123 Kozak M: Evaluation of the 'scanning model' for initiation of protein synthesis in eukaryotes. Cell 1980;22:7-8.

124 Wood MW, VanDongen HMA, VanDongen AMJ: The 5'-untranslated region of the $\mathrm{N}$ methyl- $D$-asparate receptor NR2A subunit controls efficiency of translation. J Biol Chem 1996;271:8115-8120.

125 Kean KM: The role of mRNA 5'-noncoding and 3 '-end sequences on $40 \mathrm{~S}$ ribosomal subunit recruitment, and how RNA viruses successfully compete with cellular mRNAs to ensure their own protein synthesis. Biol Cell 2003;95:129-139.
126 Mendez R, Richter JD: Translational control by CPEB: A means to the end. Nat Rev Mol Cell Biol 2001;2:521-529.

127 Lau NC, Lim LP, Weinstein EG, Bartel DP: An abundant class of tiny RNAs with probable regulatory roles in Caenorhabditis elegans. Science 2001;294:858-862.

128 Lee RC, Ambros V: An extensive class of small RNAs in Caenorhabditis elegans. Science 2001;294:862-864.

129 Lagos-Quintana M, Rauhut R, Yalcin A, Meyer J, Lendeckel W, Tuschl T: Identification of tissue-specific microRNAs from mouse. Curr Biol 2002;12:735-739.

130 Dostie J, Mourelatos Z, Yang M, Sharma A, Dreyfuss G: Numerous microRNPs in neuronal cells containing novel microRNAs. RNA 2003;9:180-186.

131 Seitz HY: Imprinted microRNA genes transcribed antisense to a reciprocally imprinted retrotransposon-like gene. Nat Genet 2003; 34:261-262.

132 Jang SK, Pestova TV, Hellen CU, Witherell GW, Wimmer E: Cap-independent translation of picornavirus RNAs: Structure and function of the internal ribosomal entry site. Enzyme 1990;44:292-309.

133 Pestova TV, Hellen CU: Functions of eukaryotic factors in initiation of translation. Cold Spring Harbor Symp Quant Biol 2001;66: 389-396.

134 Holcik M, Sonenberg N, Korneluk RG: Internal ribosome initiation of translation and the control of cell death. Trends Genet 2000;16: 469-473.

135 Schneider R, Agol VI, Andino R, Bayard F, Cavener DR, Chappell SA, Chen JJ, Darlix JL, Dasgupta A, Donze O, Duncan R, ElroyStein O, Farabaugh PJ, Filipowicz W, Gale M Jr, Gehrke L, Goldman E, Groner Y, Harford JB, Hatzglou M, He B, Hellen CU, Hentze MW, Hershey J, Hershey P, Hohn T, Holcik M, Hunter CP, Igarashi K, Jackson R, Jagus R, Jefferson LS, Joshi B, Kaempfer R, Katze M, Kaufman RJ, Kiledjian M, Kimball SR, Kimchi A, Kirkegaard K, Koromilas AE, Krug RM, Kruys V, Lamphear BJ, Lemon S, Lloyd RE, Maquat LE, Martinez-Salas E, Mathews MB, Mauro VP, Miyamoto S, Mohr I, Morris DR, Moss EG, Nakashima N, Palmenberg A, Parkin NT, Pe'ery T, Pelletier J, Peltz S, Pestova TV, Pilipenko EV, Prats AC, Racaniello V, Read GS, Rhoads RE, Richter JD, Rivera-Pomar R, Rouault T, Sachs A, Sarnow P, Scheper GC, Schiff L, Schoenberg DR, Semler BL, Siddiqui A, Skern T, Sonenberg N, Tahara SM, Thomas AA, Toulme JJ, Wilusz J, Wimmer E, Witherell G, Wormington $\mathrm{M}$ : New ways of initiating translation in eukaryotes. Mol Cell Biol 2001;21:82388246.

136 Liu A, Zhuang Z, Hoffman PW, Bai G: Functional analysis of the rat $\mathrm{N}$-methyl- $D$-aspartate receptor 2A promotor. J Biol Chem 2003; 278:26423-26434.
137 Meguro H, Mori H, Araki K, Kushiya E, Kutsuwada T, Yamazaki M, Kumanishi T, Arakawa M, Sakimura K, Mishina M: Functional characterization of a heteromeric NMDA receptor channel expressed from cloned cDNAs. Nature 1992;357:70-74.

138 Steward O, Worley P: Local synthesis of proteins at synaptic sites on dendrites: role in synaptic plasticity and memory consolidation? Neurobiol Learn Mem 2002;78:508527.

139 Steward O, Worley PF: A cellular mechanism for targeting newly synthesized mRNAs to synaptic sites on dendrites. Proc Natl Acad Sci USA 2001;98:7062-7068.

140 Torre ER, Steward O: Protein synthesis within dendrites: Glycosylation of newly synthesized proteins in dendrites of hippocampal neurons in culture. J Neurosci 1996;16:5967_ 5978.

141 Steward O, Banker GA: Getting the message from the gene to the synapse: Sorting and intracellular transport of RNA in neurons. Trends Neurosci 1992;15:180-186.

142 Carson JH, Cui H, Krueger W, Schlepchenko B, Brumwell C, Barbarese E: RNA trafficking in oligodendrocytes. Results Probl Cell Differ 2001;34:69-81.

143 Tiruchinapalli DM, Oleynikov Y, Kelic S, Shenoy SM, Hartley A, Stanton PK, Singer RH, Bassell GJ: Activity-dependent trafficking and dynamic localization of zipcode binding protein 1 and beta-actin mRNA in dendrites and spines of hippocampal neurons. $\mathrm{J}$ Neurosci 2003;23:3251-3261.

144 Snee M, Kidd GJ, Munro TP, Smith R: RNA trafficking and stabilization elements associate with multiple brain proteins. J Cell Sci 2002;115:4661-4669.

145 Richter JD, Lorenz LJ: Selective translation of mRNAs at synapses. Curr Opin Neurobiol 2002;12:300-304.

146 Jiang C, Schuman EM: Regulation and function of local protein synthesis in neuronal dendrites. Trends Neurosci 2003;27:506513.

147 Quinlan EM, Olstein DH, Bear MF: Bidirectional, experience-dependent regulation of $\mathrm{N}$ methyl- $D$-aspartate receptor subunit composition in the rat visual cortex during postnatal development. Proc Natl Acad Sci USA 1999; 96:12876-12880.

148 Quinlan EM, Philpot BD, Huganir RL, Bear MF: Rapid, experience-dependent expression of synaptic NMDA receptors in visual cortex in vivo. Nat Neurosci 1999;2:352-357.

149 Zuker M: Prediction of RNA secondary structure by energy minimization. Methods $\mathrm{Mol}$ Biol 1994;25:267-294.

150 Kozak M: An analysis of 5'-noncoding sequences from 699 vertebrate messenger RNAs. Nucleic Acids Res 1987;15:81258132 . 